ASD傾向が高い成人における感覚処理傾向と

局所・大域的逸脱に対するミスマッチ陰性電位

柳 民秀・池田 一成 (東京学芸大学教育実践研究支援センター)

\title{
ASD Traits and Sensory Profiles of Normally Developed Adults and Their Relation to Mismatch Negativity in Response to Local and Global Auditory Deviants
}

\author{
Minsu Ryu, Kazunari IkedA \\ (Center for the Research and Support of Educational Practice, Tokyo Gakugei University)
}

\begin{abstract}
According to the autism spectrum theory, it is assumed that normally developed persons with high traits of autism spectrum disorders (ASD) share sensitivity to sensory changes with people of ASD, particularly to local rather than global changes. To test this assumption, normally developed students were examined. By using the autism spectrum quotient (AQ), high and low AQ groups were assembled. Sensory processing of participants was assessed by using the adult/adolescent sensory profile (AASP). For the two groups, mismatch negativity (MMN) in response to local and global auditory changes was recorded. The high AQ group revealed a tendency to have a similar AASP to people with ASD. The MMN of the high AQ group showed that responses to global changes were larger than responses to local changes. This result suggests that the high AQ group can easily perceive patterns of local auditory changes, leading to difficulty achieving MMN in response to local changes.
\end{abstract}

Key words: autism spectrum disorders, autism spectrum quotient, sensory profile, mismatch negativity, local and global changes

2017.11.29受稿，2018.10.2受理，2019.9.19 J-STAGE早期公開，doi: 10.5674/jjppp. 1715oa

連絡者及び連絡先：テ184-8501 東京都小金井市貫井北町 4-1-1 東京学芸大学教育実践研究支援センター 池田一成 E-mail:kazunari@u-gakugei.ac.jp 
【要 約】自閉症スペクトラム仮説によれば，自閉症スペクトラム障害 (autism spectrum disorder: ASD) 傾向が 高い定型発達児者は, ASD児者と同様に, 感覚的な変化に敏感であるという特性と, 特に大域的変化に比べ局 所的変化に敏感であるという特性を持つことが推定できる。この推定が正しいかどうかを検証するために, 定型 発達の成人を対象に研究を行った。まず, 自閉症スペクトラム指数 (autism spectrum quotient: AQ) を用いて AQ 高群と AQ低群を集めた。次に, 青年成人版感覚プロファイル (adult/adolescent sensory profile: AASP)を用いて 実験参加者の感覚処理を調査した。さらに, 聴覚刺激における局所・大域的変化に対するミスマッチ陰性電位 (mismatch negativity: MMN) を記録した。その結果, AASPにおいてAQ高群にASDの成人と類似の傾向が示 された。また $\mathrm{AQ}$ 高群では, 大域的変化に対するMMNが局所的変化に対する $\mathrm{MMN} に$ 比べ大きいことが示され た。この結果は, AQ高群が局所的変化の規則的パターンを容易に知覚することにより, 局所的変化に対する MMNが生じにくくなることを示唆している。

自閉症スペクトラム障害／自閉スペクトラム症 (Autism Spectrum Disorders: ASD) は, 社会的コミュ ニケーション及び社会的相互作用の持続的な障害と, 行動・興味・活動における固定的で反復的な様式を特 徵とする発達障害である。2013年, 精神疾患の診 断・統計マニュアル第5版 (Diagnostic and Statistical Manual of Mental Disorders, Fifth Edition: DSM-5) において，以前までは知的機能に障害の無い自閉性障 害として別のカテゴリーに属していたアスペルガー症 候群がASDの中に統合された (American Psychiatric Association, 2013)。これは, 自閉性障害とアスペル ガー症候群は社会的・コミュニケーション障害の連続 体上にあり，アスペルガー症候群が自閉性障害と定型 発達との間に位置する存在であるという仮説 (BaronCohen et al., 1995; Frith et al., 1991; Wing, 1981)に 基づいている。この自閉症スペクトラム（連続体）仮 説は，ASD と定型発達児者との連続性が仮定される ことから, 臨床テーマについて非臨床群を対象として 研究を行うアナログ研究の可能性を示唆するものであ る(若林ら，2004）。

Baron-Cohen et al. (2001)は, この仮説をもとに, 健常範囲の知能を持つ成人の ASD 傾向 (特性) あるい はその幅広い表現型の程度を測定可能な, 自己回答式 の尺度である自閉症スペクトラム指数 (Autism spectrum Quotient: AQ) を作成した。自閉症スペクト ラム指数は日本語版 (AQ-J) も作成されており（若林 ら，2004），ASDのスクリーニングや研究等に広く用 いられている。

$\mathrm{AQ}$ の項目は, $\mathrm{ASD}$ を特徵づける5つの領域（社会 的スキル，コミュニケーション，想像力，注意の切り 替え, 細部への注意) で構成されている。質問項目は
全部で50項目と比較的少なく，実施が簡便である。 AQ は臨床的スクリーニングに使用できるだけではな く, 定型発達の成人の自閉症傾向の個人差を測定でき るなど, 診断と研究の両面に有益であるとされている (若林ら，2004）。

ASDには, 上述の特徵以外に, 感覚刺激に対する 反応が定型発達とは異なるという特徵がある。 DSM-5 の診断基準に,「感覚入力に対する敏感性ある いは鈍感性，あるいは感覚に関する環境に対する普通 以上の関心」という項目が追加されたが，これは, ASDの感覚異常に対する報告が蓄積されてきた結果 であるといえる。例えば, Leekam et al. (2007)は, 研究参加者であるASDの子どもの $90 \%$ 以上に感覚的 な異常がみられたことを報告している。

$\mathrm{ASD}$ の感覚処理傾向について理解し, 適切な支援 を行うためには, 感覚処理傾向を測定するッールの活 用が重要であると考えられる。Dunn（1997）は，定 型発達児を対象とした研究結果から, 神経学的間值と 行動反応・自己調節との関連性を示す概念モデルを導 いた。このモデルでは, 神経学的閾值の連続体と行動 反応・自己調節の連続体が互いに作用しあうことを想 定している。神経学的閾値とは，ニューロン，または ニューロン系の反応に必要な刺激の量を示し, この連 続体の一端は高閾値，もう一端は低閾值となる。行動 反応・自己調節とは，人がその閾值に応じてどのよう に反応するかを示し，この連続体の一端では，感覚刺 激に対する受動的反応, もう一端は, 感覚刺激に対す る能動的反応を示す。この2つの連続体は互いに交差 していると仮定され，それによって区分された4象限 (低登録, 感覚探求, 感覚過敏, 感覚回避) によって, 感覚処理のパターンが説明される。「低登録」は, 神 
経学的高閾值・受動的反応に対応する。「低登録」の 人は，他の人が気づいている刺激に対して反応をしな い, もしくは反応に時間がかかる傾向がある。「感覚 探求」は, 神経学的高閾值・能動的反応に対応する。 「感覚探求」の行動をとる人は, 神経学的閾值を満た すため，感覚刺激となるような刺激を作り出したり， 刺激を得る環境を探したりする傾向がある。「感覚過 敏」は, 神経学的低闇值・受動的反応に対応する。「感 覚過敏」の人は, 神経学的閾值が低いため, 感覚刺激 に容易に反応する傾向がある。「感覚回避」は, 神経 学的低闇值 - 能動的反応に対応する。「感覚回避」の 行動をとる人は，感覚刺激に圧倒されている，または 困難を感じているため, 感覚刺激を避ける傾向があ る。Dunn（1999）はこの概念モデルに基づき，6-10 歳の子どもの感覚処理傾向を測定できる質問紙であ る, 感覚プロファイル (Sensory Profile: SP) を作成し た。また, Brown \& Dunn(2002)は11—65歳を対象 とした自己記述式の質問紙である青年・成人感覚プロ ファイル (Adolescent/Adult Sensory Profile: AASP) を作成した。

Crane et al.（2009）は, ASDの成人の感覚処理傾向 についてAASPによる自己評価に基づいて研究を行っ た。その結果, ASDの成人は4象限のうち, 「低登 録」,「感覚過敏」,「感覚回避」の象限におけるスコア が, 定型発達の成人に比べ有意に高いことが示され た。また，研究に参加したASDの成人のうち $94.4 \%$ が，4象限のうちの少なくとも一つに，スコアが極端 に高いもしくは低いといった感覚処理の異常を示した ことが報告されている。

また，ASDは聴覚刺激における局所的な変化の探 知に優れていることが行動指標による研究で示されて いる。以下の研究における局所的な変化とは前の音よ りも次の音が 1 音上がるなどの部分的な音程の変化を 指し, 一方大域的変化とはメロディー全体の音程が 1音下がるなどの全体的な変化を指す。Heaton et al. （1999）は，ASDの成人は定型発達の成人に比べ, 音 程の差異を判別する能力が優れていることを示してい る。また, Mottron et al. (2000)は, ASDにおける聴 覚刺激に対する大域・局所処理について研究を行い, $\mathrm{ASD}$ の成人は定型発達の成人と比較して, 大域的な 処理は障害されていないが, 局所的な音程の変化の探 知がより優れていることを示した。
行動指標による大域・局所処理の研究がある一方, 生理指標による研究は少ない。Gomot et al. (2002) は, ミスマッチ陰性電位 (mismatch negativity: MMN) を指標とした研究を行い，ASDの子どもは定型発達 の子どもに比べ聴覚刺激の変化に対する $\mathrm{MMN}$ の頂点 潜時が短いことを示した。しかし，この研究は行動指 標による研究で言うところの局所的な変化に対する反 応を調べたのみで，大域的な変化に対する反応につい ては検討していない。

以下に述べる $\mathrm{MMN}$ の特性を利用すると, 大域的変 化と局所的変化の両方を研究できる可能性がある。 MMNは, Näätänen et al. (1978)によって発見された 事象関連電位 (event-related potential: ERP) で, 同じ 刺激が繰り返し呈示されたのちに，それとは異なる刺 激が呈示されることによって, 潜時 100-250 msに 出現する。MMNの実験に多く用いられる刺激系列は オドボール系列である。オドボール系列は, 呈示頻度 の異なる2種類の刺激, すなわち高頻度の標準刺激 (standard) と, 低頻度の逸脱刺激 (deviant) がランダ ム順に呈示される。オドボール系列の呈示中にERP を測定し, 逸脱刺激によって得られる波形から標準刺 激によって得られる波形を引き算すると, MMNは抽 出される。MMNが誘発されるには2つの過程がある と考えられている (Sussman, 2007)。一つ目は, 標準 刺激の聴覚記憶を保持する過程で, 標準形成 (standard formation) と呼ばれる。二つ目は, 標準形 成過程で作られた記憶と新規に呈示された刺激との差 異を探知する過程で, 冕脱探知 (deviance detection) と呼ばれる。このように MMNが出現するためには, 標準刺激に対する聴覚記憶の形成が必要不可欠である と考えられている。

1 音が標準刺激として聴覚記憶に保持される場合だ けではなく, 複数の音のセットが標準刺激として聴覚 記憶に保持される場合もある。例えば，A音が4回呈 示され5回目にB音が呈示されるというように, 規則 的なパターン (AAAAB) が短い SOAで繰り返し呈示

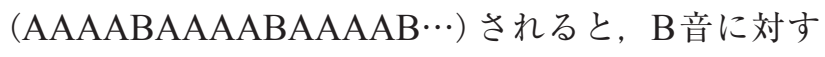
るMMNが出現しなくなる (Sussman \& Gumenyuk, 2005; Sussman et al., 1998, 2002)。この現象は, AAAAB という刺激パターンが標準的な規則性とし て聴覚記憶に保持されたために生じたと説明されてい る。以上で述べた MMNの特性を利用し, 音程の変化 
を局所的逸脱, 刺激パターンの変化を大域的逸脱とす れば, MMNを指標として局所・大域処理の研究を行 うことが可能になると考えられる。

以上の先行研究から, ASDは定型発達児者に比べ 感覚刺激に対する反応が異なることが，質問紙による 自己評価に基づいて示されている。また，局所的変化 に対し敏感であるということが生理指標や行動指標に よる他覚評価に基づいて示されている。このような 2つの特性は, ASDと診断されていない人の中でも ASD傾向が高ければ，同様に見られる可能性がある。 自閉症スペクトラム仮説は, 社会的・コミュニケー ション障害の連続体を仮定した説であるが，社会的・ コミュニケーション障害とASDにみられるその他の 特性とは相互に影響し合っていると考えられる。例え ば，感覚過敏の傾向が高ければ感覚刺激に多くさらさ れる社会的場面は回避すると考えられ，逆に感覚鈍麻 の傾向が高ければ他者に注意が向きづらくコミュニ ケーションがうまく取れないと考えられる。ASD傾 向と感覚処理傾向が相互に影響し合っているとすれ ば, ASD特有の感覚処理傾向においてもASD傾向と 同様に定型発達との間に連続体が存在することが推測 される。また，ASDは局所的変化に敏感であり大域 処理よりも局所処理が優勢に行われる傾向があるが, 大域的変化の知覚自体は障害されていないとされてい る。そのため, 刺激の呈示方法を工夫すれば, 局所的 変化よりも大域的変化を優勢に行うように誘導できる 可能性がある。本研究において大域的変化を優勢に行 うように誘導する刺激呈示方法を示すことができれ ば，大域処理が必要な場面においてどのような環境整 備が必要かを考える材料になると考えられる。

以上のことを踏まえ, 本研究の目的は, 以下につい て検討することである。第 1 に, ASD と定型発達者と の間にある感覚処理傾向の連続性について検討する。 そのために, AQにより, 定型発達の成人を ASD傾向 の高いグループと低いグループに分けAASPを実施す る。その結果, もしASD傾向の高い成人に, ASDの 成人にみられるAASPのスコアパターンと類似の傾向 が見られれば, ASD と定型発達者との間に感覚処理 傾向の連続性が想定できると考えられる。第2に, ASD傾向の高低と局所的逸脱や大域的逸脱に対する 反応との間の関連を生理指標に基づき検討する。その ために, 局所的逸脱を前の音と次の音の音程の変化
(AAAAB)，大域的逸脱を刺激系列のパターンの変化 (AAAAB AAAAB AAAAA) とし，逸脱に対する MMNを測定する。ASD傾向が高い成人も ASD と同 様に局所的変化に敏感であるという特性を持つとすれ ば，ASD傾向が高い成人の局所的逸脱に対する $\mathrm{MMN}$ 振幅は, ASD傾向が低い成人よりも大きいこ とが予想される。もし，ASD傾向が高い成人と低い 成人との間に局所・大域的逸脱に対するMMNにおい て差が見られれば, ASD傾向と局所的逸脱に敏感で あるという特性との関連を, 生理指標により示すこと ができると考えられる。第 3 に, 大域的な逸脱を強調 する刺激呈示により, 大域的冕脱に対する処理を促進 できるかどうかを検討する。そのために，逸脱に対す る MMNを測定する際, パターン間に間隔が有る条件 と無い条件を設定する。もし，パターン間の間隔が有 る条件で大域的逸脱に対する MMN振幅が大きけれ ば，パターン間隔は大域的逸脱に対する処理を促進し たと考えられる。

\section{方 法}

本研究は実験参加者の選定, 感覚処理傾向の調査, ERP実験の3つの過程に分けられる。以下では, 3つの 過程に分けて本研究の方法を説明する。な掞本研究は 東京学芸大学研究倫理委員会の承認を得て実施した。

\section{参加者}

18-29歳の成人を対象に, 自閉症傾向を測定でき る尺度である自閉症スペクトラム指数 (Autism spectrum quotient: AQ) を用いたアンケートを実施し た。AQは, 健常範囲の知能を持つ成人の自閉症傾向 (特性) あるいはその幅広い表現型の程度を測定でき る尺度である。AQの項目内容は, ASDの症状を特徵 づける5つの領域（「社会的スキル」「注意の切り替え」 「細部への注意」「コミュニケーション」「想像力」)に ついて各 10 問ずつ全体で 50 項目から構成されてい

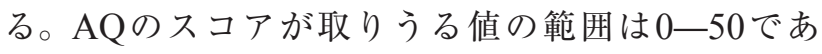
り，カットオフポイントは33点以上である。33点以 上には，ASD群の $87.8 \%$ が含まれる。

アンケートには, 株式会社マクロミルのWEBアン ケートッール「Questant」を利用した。本サイトの URLを知人もしくはその知人を介して不特定多数に 
Table 1. Means, standard deviations $(S D)$, and ranges for AQ scores.

\begin{tabular}{cccr}
\hline Group (AQ) & Mean & $S D$ & Range \\
\hline High AQ $(n=12)$ & 28.92 & 3.37 & $25-35$ \\
Low AQ $(n=12)$ & 10.92 & 2.88 & $6-14$ \\
\hline
\end{tabular}

送信した。アンケートに回答するかどうかは, URL が送られた当人の自由とした。回答者は合計 122 名で あった。また，アンケートには連絡先を記入する闌を 設け, 連絡先を記入した回答者に実験参加の要請を行 う可能性があることを説明した。連絡先を記入した回 答者の中から, $\mathrm{AQ}$ 得点の高い順に連絡を取り, 実験 参加の了承を得ることができた 12 名 (女性 8 名, 平均 年齢22.3歳, 年齢の範囲20-24歳) を $\mathrm{AQ}$ 高群とし た。また, $\mathrm{AQ}$ 得点の低い順に連絡を取り, 実験参加 の了承を得ることができた 12 名 (女性 8 名, 平均年齢 23 歳, 年齢の範囲 18-26歳）を $\mathrm{AQ}$ 低群とした。以 上のように選出した $\mathrm{AQ}$ 高群・ $\mathrm{AQ}$ 低群合わせて24名 を対象として実験を行った。実験参加者の AQ の結果 は，本人が希望したときに限り開示した。各群の $\mathrm{AQ}$ の平均值と標準偏差, 得点の範囲を Table 1 に示す。

\section{感覚処理傾向の調査}

材料 日本版青年・成人感覚プロファイル（日本版 AASP）を用いた。以下では, 日本版AASPの概要に ついて, 日本版青年・成人感覚プロファイル ユー ザーマニュアル（萩原ら，2015）を基に説明する。日 本版AASPは自己評定形式の質問票であり，その対象 年齢は11-82歳である。AASPは, 感覚処理の特性 評価を目的としており, 質問には, 自分が感覚刺激に 対して通常どう反応するかを，「ほとんどしない」「ま れに」「ときどき」「しばしば」「ほとんどいつも」の5 段階で回答し, 各回答に1-5点のいずれかが与えら れる。AASPの回答を基に,「低登録」「感覚探求」「感 覚過敏」「感覚回避」の象限スコアが得られ, 回答者 の感覚処理のパターンを明らかにすることができる。 AASPの質問項目は, 各象限ごとに15項目ずつ, 計 60 項目で構成されている。各象限のスコアが取りう る值の範囲は15-75である。

記録・分析 参加者にAASPを実施した。実施の際 には質問項目に関する質問を許可し，質問があった場
合はマニュアルに従い適宜回答した。日本版AASPの 回答を基に, 各実験参加者の4象限ごとのスコアを算 出した。各象限の得点を従属変数として, グループ $(\mathrm{AQ}$ 高群, $\mathrm{AQ}$ 低群 $) \times$ 感覚処理象限 $($ 低登録, 感覚 探求, 感覚過敏, 感覚回避) の2 要因分散分析を行っ た。

\section{ERP実験}

刺激と条件 聴覚刺激として, A 音 (周波数 $1,000 \mathrm{~Hz}$ ) が4つとB音 (周波数 $1,100 \mathrm{~Hz}$ ) が1つからなるパター ン (AAAAB) が $80 \%$ の頻度で, $\mathrm{A}$ 音が5つからなるパ ターン (AAAAA) が20\%の頻度で呈示される系列音 を用いた (Figure 1A)。この系列音はBekinschtein et al.（2009）を参考に作成した。A音，B音ともに，持 続時間 $60 \mathrm{~ms}$, 立ち上がり／立ち下がり各 $5 \mathrm{~ms}$, 音圧 $70 \mathrm{~dB}$ SPLとした。パターン内の音に対し, 呈示順に 番号を割り当て, A1一A4は標準刺激, B は局所的逸 脱刺激，A5 は大域的逸脱刺激とした (Figure 1A)。聴 覚刺激は，パターン間隔が有る条件（間隔有り条件） と無い条件 (間隔無し条件)で呈示した (Figure 1B)。 両条件において, パターン内の刺激間間隔は $140 \mathrm{~ms}$ (SOAは200 ms) とした。間隔有り条件におけるパ ターン間の間隔は, $1,440 \mathrm{~ms}(\mathrm{SOA} は 1,500 \mathrm{~ms})$ と し，間隔無し条件におけるパターン間の間隔はパター ン内と同じく $140 \mathrm{~ms}(\mathrm{SOA} 2200 \mathrm{~ms})$ とした。間隔 有り条件と間隔無し条件の呈示順序は実験参加者ごと にバランスさせた。聴覚刺激はヘッドフォンから呈示 された。 $\mathrm{MMN}$ は無意識の自動的処理を反映している ため聴覚刺激に注意が向かない状態で測定される。実 験参加者の注意が聴覚刺激に向かないようにするため の手続きとして, 聴覚刺激と同時に視覚刺激を呈示し た。視覚刺激として, 実験参加者の希望をもとに用意 した無音のDVD映像を用いた。視覚刺激は実験参加 者の正面に置かれたテレビ画面から呈示された。刺激 と条件の組み合わせは, (1)間隔有り条件・局所的逸脱 刺激, (2)間隔有り条件 ·大域的逸脱刺激, (3)間隔無し 条件 - 局所的逸脱刺激, (4)間隔無し条件 - 大域的逸脱 刺激の4パターンあることになる。

記録・分析 刺激呈示中の脳波を計測した。脳波の 記録にはメロンテクノス株式会社の $32 \mathrm{ch}$ セパレート 型生体アンプを使用した。電極は $\mathrm{Ag}-\mathrm{AgCl}$ 血電極を 使用した。鼻尖を基準電極とし, 国際 10-20法に基づ 


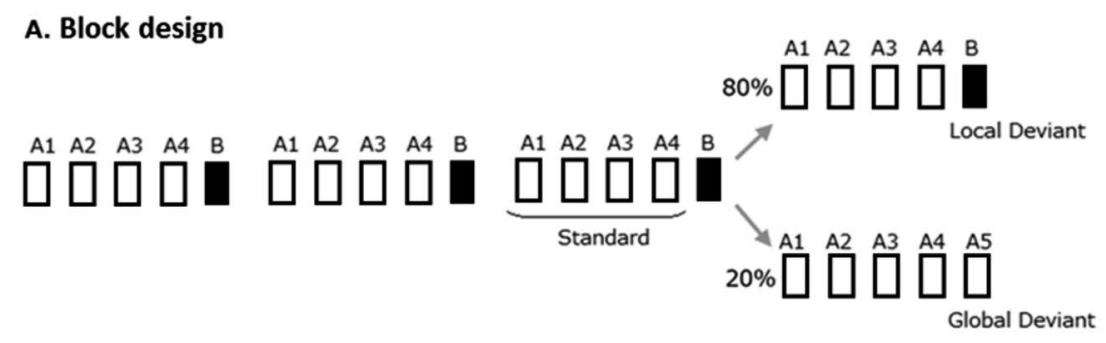

\section{B. Condition}
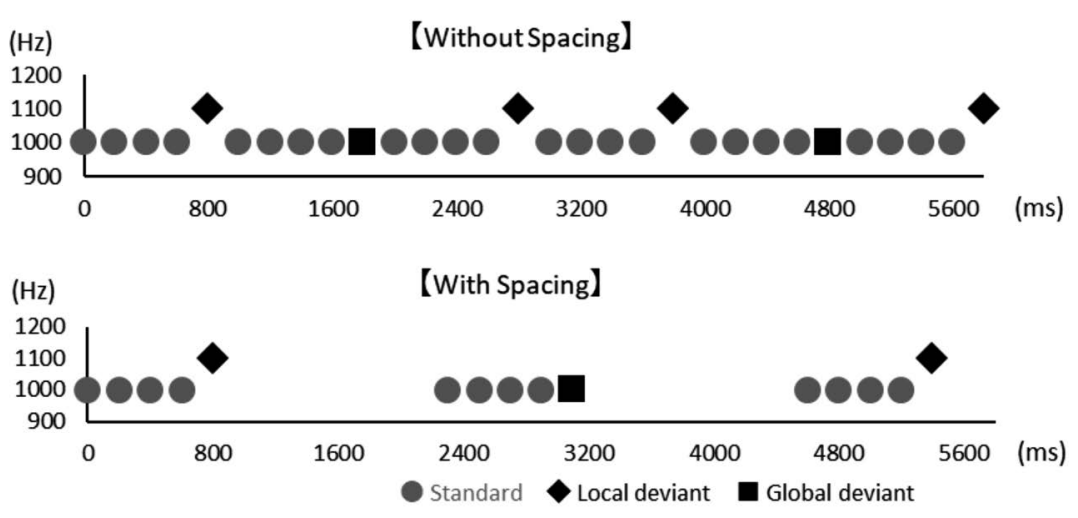

Figure 1. Block design and condition in the experiment.

き, 探查電極を $\mathrm{Fz}, \mathrm{Cz}, \mathrm{C} 3, \mathrm{C} 4$, 左右マストイド (M1, M2)に置き脳波を測定した。時定数は $3 \mathrm{~s}$, サンプリ ング周波数は $10 \mathrm{KHz}$ に設定した。ローパスフィル夕 にはベッセルタイプのフィルタを用い, 高域遮断周波 数は $63 \mathrm{~Hz}(-3 \mathrm{~dB})$ に設定した。加算平均区間におい て $\pm 75 \mu \mathrm{V}$ を超える電位はアーチファクトとして除去 するように設定した。最初に刺激開始前 $30 \mathrm{~ms}$ から刺 激開始後 $100 \mathrm{~ms}$ までの区間の脳波を測定した。刺激 は加算回数が 150 に達するまで呈示した。次にオフラ インで再加算を行った。その際, 刺激開始前 $100 \mathrm{~ms}$ をベースラインとし, 刺激開始後 $500 \mathrm{~ms}$ までの計 $600 \mathrm{~ms}$ の範囲に加算平均区間を設定し直した。その 結果, 各刺激の加算回数が不揃いとなったため, 同一 の実験参加者では少ないほうの加算回数に合わせ無作 為に試行を除くことで，各音刺激 $(\mathrm{A} 1$-A4, A5, B), 条件間 (間隔有り条件・間隔無し条件) で加算回数が 等しくなるようにした。各実験参加者の加算回数は 81-137回（平均99.96回）であった。

測定した脳波から, 標準刺激である4つのA音に対 するERP波形の平均 $(\mathrm{A}$ 波形) と局所的逸脱刺激であ る $\mathrm{B}$ 音に対する $\mathrm{ERP}$ 波形 ( $\mathrm{B}$ 波形), 大域的冕脱刺激 であるA5に対する $\mathrm{ERP}$ 波形 (A5 波形)を得た。 $\mathrm{B}$ 波 形から A波形を減じることによって, 局所的逸脱に対
する差波形を得た。また，A5波形から A 波形を減じ ることで，大域的逸脱に対する差波形を得た。

ERPの分析は以下の手順で行った。第 1 に, 各実験 参加者の局所的逸脱に対する差波形と大域的逸脱に対 する差波形それぞれにおける MMN振幅を算出した。 まず，電極部位Fzで得られる局所的逸脱に対する差 波形（もしくは大域的逸脱に対する差波形）の総加算 平均波形に打ける，100-250 msの区間の最大陰性振 幅值の潜時を MMNの頂点潜時とし，条件ごとに頂点 潜時を算出した。次に, 各条件の頂点潜時を中心に $20 \mathrm{~ms}$ の区間に打ける平均振幅を MMN振幅とし, 実 験参加者ごとに算出した。

第2に, MMNが出現したと言えるかどうかを検討 した。MMNの同定にはNäätänen et al. (2004)の方 法を用いた。まず，Fzにおける局所的逸脱に対する 差波形から左右マストイドにおける差波形の平均を減 じ，Fz-M波形を条件ごとに導出した。大域的逸脱に 対する差波形においても同様の方法で, Fz-M波形を 得た。次に, Fz-M波形における刺激呈示後100— $250 \mathrm{~ms}$ 区間の頂点潜時を中心に $20 \mathrm{~ms}$ の区間の平 均振幅 $(M M N$ 振幅)を, 実験参加者ごとに算出した。 最後に, $\mathrm{MMN}$ 振幅の平均值について, 条件ごとに0 との $t$ 検定 (片側検定)を行い, 有意差が見られた条件 
柳・池田：感覚処理傾向と局所・大域的逸脱の MMN

Table 2. Means and standard deviations for AASP scores

\begin{tabular}{ccccc}
\hline \multirow{2}{*}{ Group (AQ) } & \multicolumn{4}{c}{ AASP score } \\
\cline { 2 - 5 } & Low registration & Sensation seeking & Sensory sensitivity & Sensation avoiding \\
\hline High AQ $(n=12)$ & $39.25 \pm 6.32$ & $38.08 \pm 7.81$ & $43.83 \pm 5.87$ & $43.58 \pm 6.46$ \\
Low AQ $(n=12)$ & $28.42 \pm 4.17$ & $45.17 \pm 7.27$ & $34.42 \pm 6.82$ & $33.34 \pm 7.25$ \\
\hline
\end{tabular}

$($ Mean $\pm S D)$

において MMNが出現したと判断した。この方法は, $\mathrm{MMN}$ の極性がFzとマストイドでは反転するという 特性を利用した方法である。

第3に，局所的逸脱に対する差波形と大域的逸脱に 対する差波形の $\mathrm{MMN}$ 振幅における条件間の違いにつ いて分析を行った。MMNはFzにおいて最も顕著に 表れる傾向があるため, Fzにおける局所的逸脱に対 する差波形と大域的逸脱に対する差波形の MMN振幅 (鼻尖基準)を従属変数とした, グループ (AQ高群, $\mathrm{AQ}$ 低群) メパターン間隔 (間隔有り, 間隔無し) ×冕 脱の種類 (局所, 大域)の3要因分散分析を行った。

分散分析を行う際に, 単純主効果の検定には, Bonferroni法による調整を行った。また, Mauchlyの 球面性検定によって水準間に球面性が仮定できない場 合は, 適宜Greenhouse-Geisserのとにより自由度の調 整を行い, 分析を行った。

\section{結 果}

\section{AQ と AASP}

日本版AASPの各象限に扔ける平均值と標準偏差を Table 2に示す。日本版AASP の各象限の得点を従属 変数として, グループ ( $\mathrm{AQ}$ 高群, $\mathrm{AQ}$ 低群 $) \times$ 感覚処 理象限 (低登録, 感覚探求, 感覚過敏, 感覚回避) の 2要因分散分析を行った。その結果, グループの要因 に主効果が認められ，AQ高群の方が $\mathrm{AQ}$ 低群よりも AASPのスコアが有意に高いことが示された $(F(1$, 22) $\left.=15.235, p=.001, \eta_{\mathrm{p}}^{2}=.409\right)$ 。また, グループと 感覚処理象限との間に交互作用が認められた $(F(3$, 66) $\left.=11.277, p<.001, \eta_{\mathrm{p}}^{2}=.339\right)$ 。単純主効果の検定 の結果, 低登録 $(p<.001)$, 感覚過敏 $(p<.01)$, 感覚 回避 $(p<.01)$ のスコアは, $\mathrm{AQ}$ 高群の方が $\mathrm{AQ}$ 低群よ りも有意に高いことが示された。一方, 感覚探求のス コアは $\mathrm{AQ}$ 高群に比べ $\mathrm{AQ}$ 低群の方が有意に高いこと
が示された $(p<.05)$ 。

\section{$\mathrm{AO}$ と ERP}

ERP波形 MMNが最も顕著に表れるFzにおける $\mathrm{A}$ 波形，B波形，A5 波形を Figure 2 に示す。また，局 所的逸脱に対する差波形 (B-A) と大域的逸脱に対す る差波形 (A5-A) をFigure 3に示す。

MMNの同定 MMN同定のための $t$ 検定 (片側検 定）の結果， $\mathrm{AQ}$ 高群の間隔有り条件に扔ける局所的 冕脱に対する差波形を除く全ての波形において，0 の間に有意差が認められた。つまり，この方法によれ ば，AQ高群の間隔有り条件における局所的逸脱に対 する差波形以外の波形においてMMNが出現したと判 断できる (Table 3)。

各条件間の比較 $\mathrm{MMN}$ 振幅の各条件における記述 統計量をTable 4に示す。FzにおけるMMN振幅のグ ラフをFigure 4 に示す。Fzに打ける局所的逸脱に対 する差波形と大域的逸脱に対する差波形の $\mathrm{MMN}$ 振幅 を従属変数とした，グループ ( $\mathrm{AQ}$ 高群, $\mathrm{AQ}$ 低群 $) \times$ 条件 (間隔有り, 間隔無し) $\times$ 逸脱の種類 (局所, 大 域）の3要因分散分析を行った。その結果, グループ と冕脱の種類との間に交互作用が認められた $(F(1$, $\left.22)=6.509, p=.018, \eta_{\mathrm{p}}^{2}=.228\right)$ 。単純主効果の検定の 結果, 局所的逸脱に対する差波形に扔いて, AQ高群 よりも $\mathrm{AQ}$ 低群の方が, $\mathrm{MMN}$ 振幅が有意に大きいこ とが示された $(p<.05)$ 。また, 条件と逸脱の種類との 間に交互作用が認められた $(F(1,22)=6.107$, $\left.p=.022, \eta_{\mathrm{p}}^{2}=.217\right)$ 。大域的逸脱に対する差波形に掠 いて, 間隔有り条件の方が間隔無し条件よりも MMN 振幅が有意に大きいことが示された $(p<.05)$ 。さら に, 間隔有り条件において, 局所的逸脱に対する MMN振幅よりも大域的逸脱に対するMMN振幅の方 が有意に大きいことが示された $(p<.05)$ 。その他の主 効果・交互作用は有意ではなかった $(p>.05)$ 。 


\section{Local Deviant}

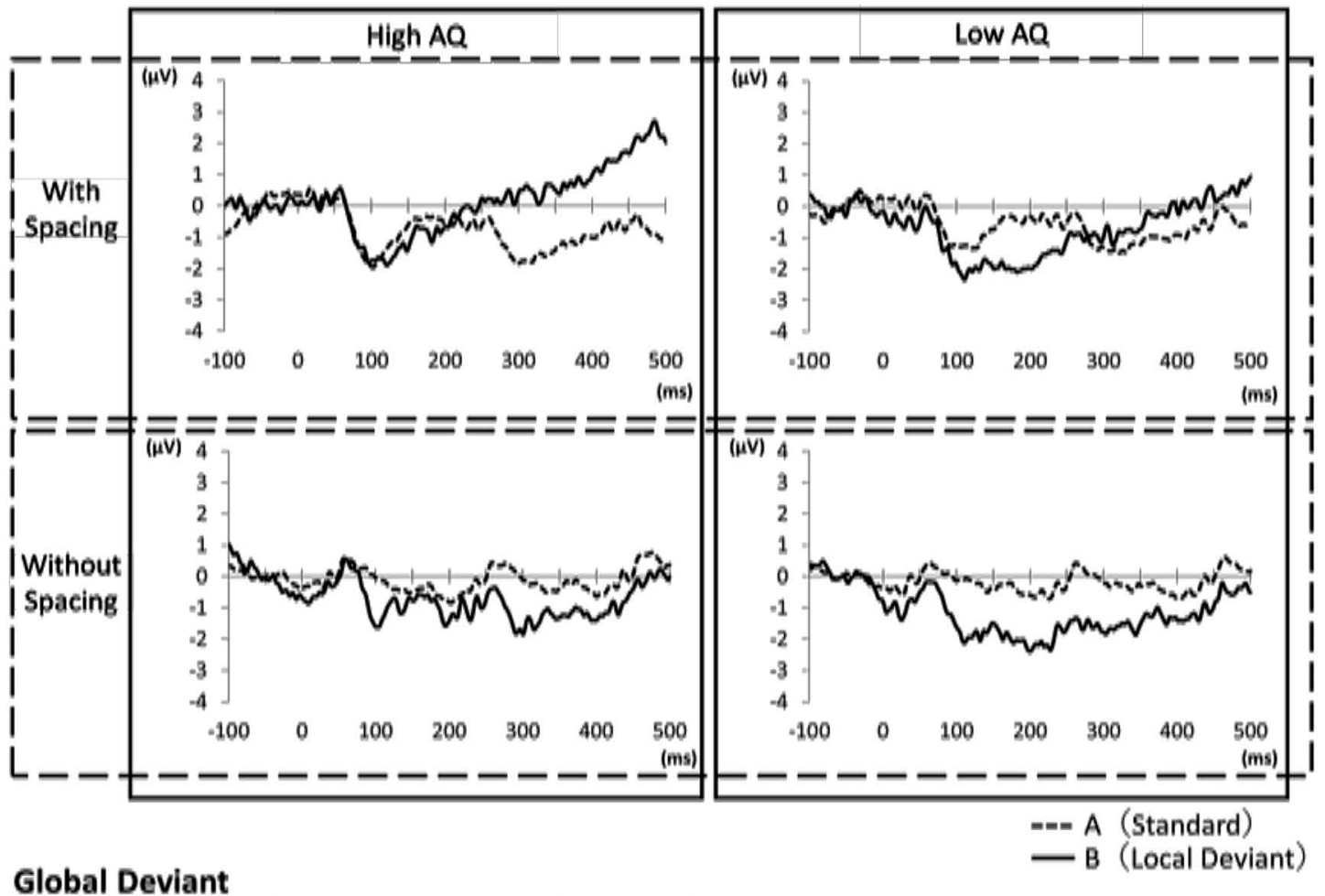

Global Deviant

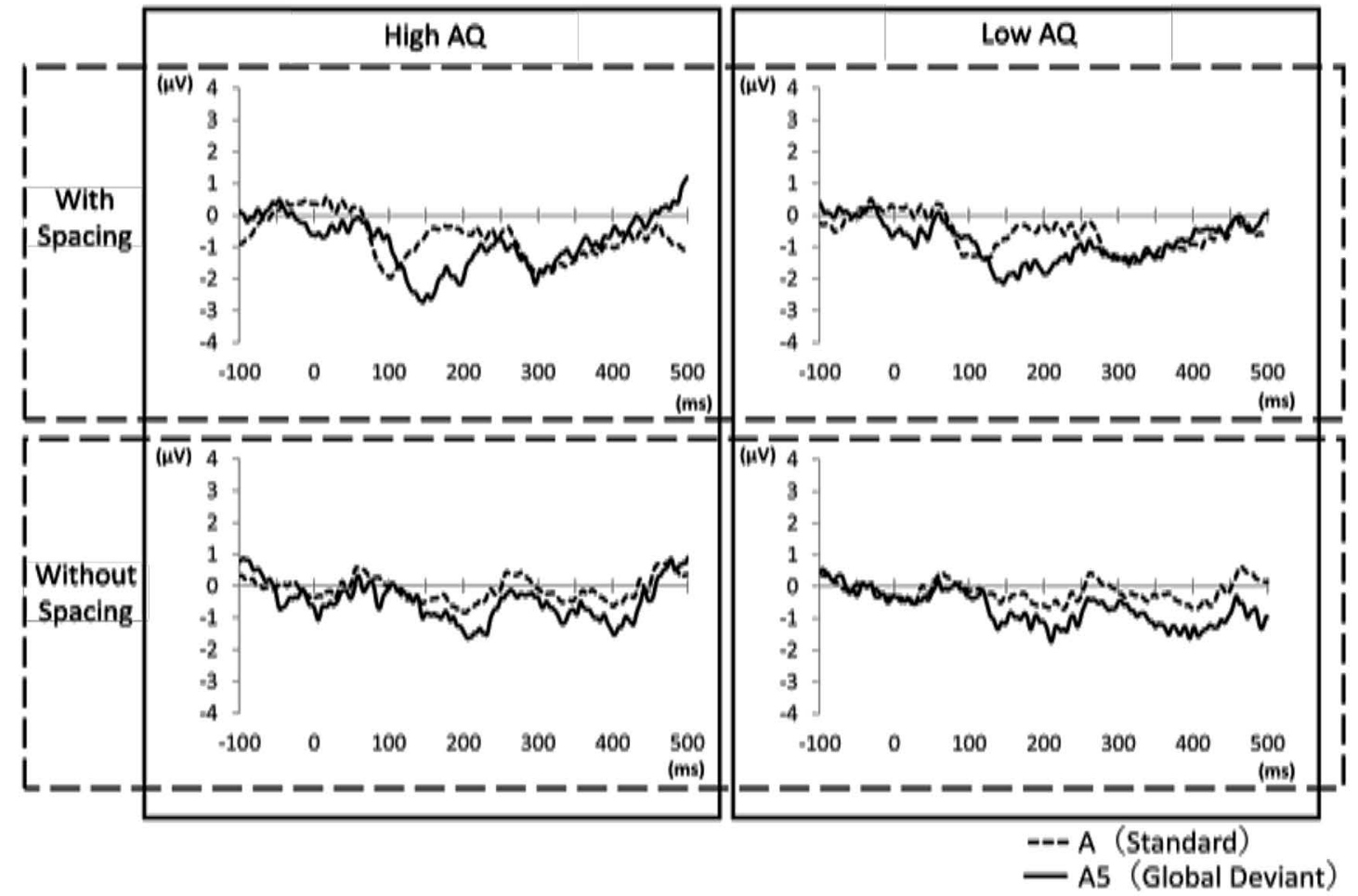

Figure 2. Grand average waveforms for standards and deviants.

考 察

本研究では，第1に，ASDと定型発達者との間にあ る感覚処理傾向の連続性について検討した。第2に,
ASD傾向の高低と局所的逸脱や大域的逸脱に対する 反応との間の関連を生理指標に基づき検討した。第 3 に，大域的な逸脱を強調する刺激呈示により，大域的 逸脱に対する処理を促進できるかどうかを検討した。 


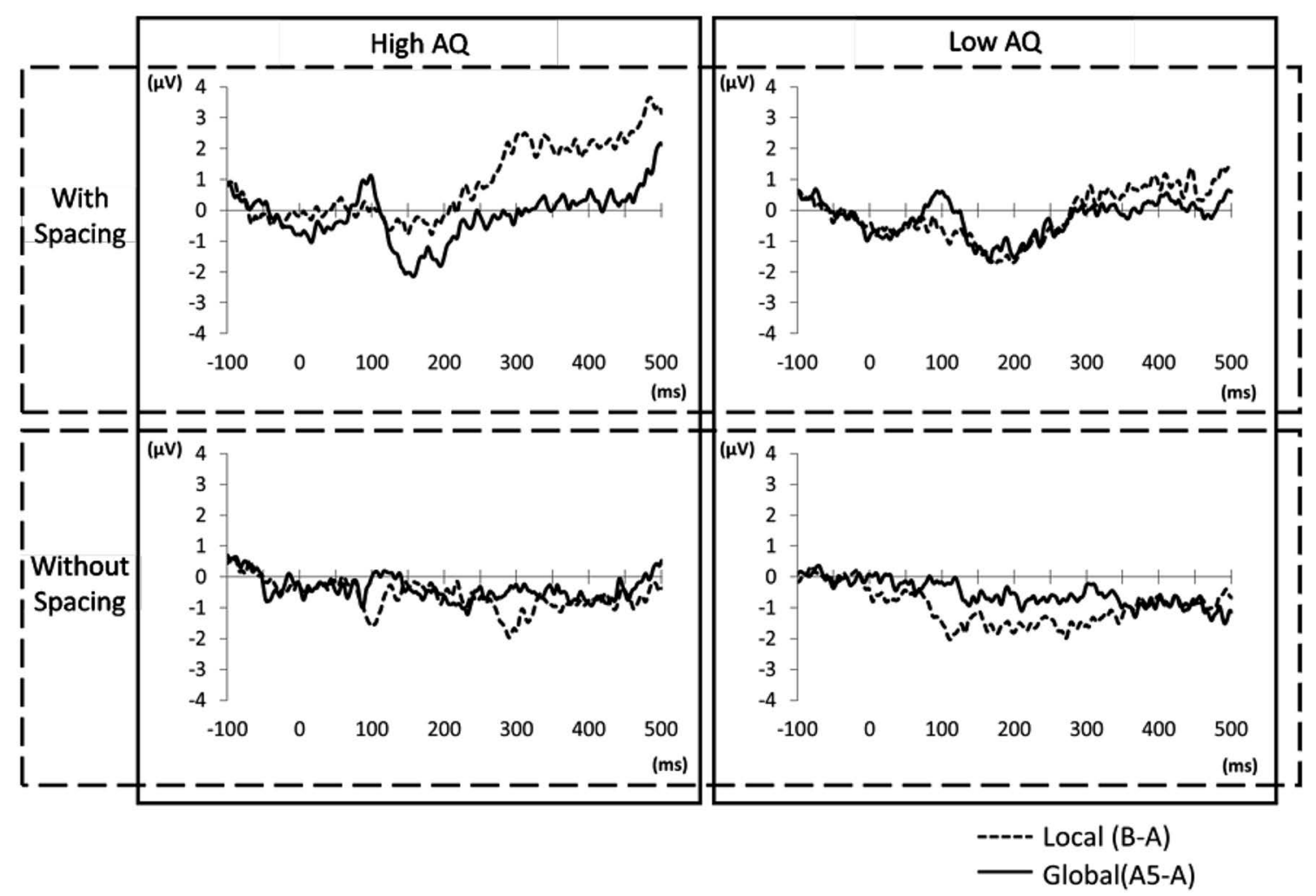

Figure 3. Difference waveforms (deviant minus standard) for Local or Global deviance.

Table 3. Means and standard deviations for MMN latency and amplitude of Fz-M waveform, with t-test results of amplitudes

\begin{tabular}{ccccc}
\hline Group (AQ) & Condition & Type of deviation & Mean latency $\pm S D$ & Mean amplitude $\pm S D$ \\
\hline \multirow{2}{*}{ High AQ } & With spacing & Local & $195.7 \pm 13.13$ & $-0.62 \pm 1.39$ \\
& & Global & $153.0 \pm 10.05$ & $-2.37 \pm 1.83^{* * *}$ \\
& Without spacing & Local & $101.0 \pm 10.20$ & $-1.66 \pm 1.08^{* * *}$ \\
& & Global & $231.9 \pm 12.05$ & $-1.05 \pm 0.97^{* *}$ \\
Low AQ & With spacing & Local & $180.9 \pm 15.96$ & $-1.89 \pm 1.15^{* * *}$ \\
& & Global & $160.2 \pm 12.07$ & $-1.66 \pm 2.00^{* *}$ \\
& Without spacing & Local & $113.4 \pm 13.84$ & $-1.61 \pm 1.76^{* *}$ \\
& & Global & $211.8 \pm 12.61$ & $-0.54 \pm 0.76^{*}$ \\
\hline
\end{tabular}

${ }^{*} p<.05,{ }^{* *} p<.01,{ }^{* * *} p<.001$

以下では, その結果について考察する。

\section{ASD傾向と感覚処理傾向}

日本版AASPの各象限の得点を従属変数とした，グ ループ (AQ 高群, $\mathrm{AQ}$ 低群) $\times$ 感覚処理象限（低登録, 感覚探求, 感覚過敏, 感覚回避) の2要因分散分析の 結果,「低登録」「感覚過敏」「感覚回避」の得点は AQ 低群より $\mathrm{AQ}$ 高群の方が高く, 逆に, 「感覚探求」の得
点は $\mathrm{AQ}$ 高群よりも $\mathrm{AQ}$ 低群の方が高いことが示され た。

この結果は, Crane et al. (2009) が成人の ASDを対 象にして行った研究の結果と一致している。つまり, 本研究に扔ける結果から, ASD傾向が高い定型発達 の成人においても, ASDの成人と同様の感覚処理傾 向があると考えられる。

$\mathrm{ASD}$ 傾向が高い成人も, ASDの成人と同様の感覚 
Table 4. Means and standard deviations for MMN mean amplitudes

\begin{tabular}{|c|c|c|c|c|c|c|c|}
\hline \multirow{2}{*}{ Group (AQ) } & \multirow{2}{*}{ Condition } & \multirow{2}{*}{ Type of deviation } & \multicolumn{5}{|c|}{ Electrode } \\
\hline & & & $\mathrm{Fz}$ & $\mathrm{Cz}$ & $\mathrm{Pz}$ & $\mathrm{C} 3$ & $\mathrm{C} 4$ \\
\hline \multirow[t]{8}{*}{ High AQ } & With spacing & Local & -0.17 & -0.02 & -0.11 & -0.01 & -0.14 \\
\hline & & & \pm 1.02 & \pm 1.09 & \pm 1.16 & \pm 0.74 & \pm 0.75 \\
\hline & & Global & -1.81 & -1.53 & -0.93 & -1.25 & -1.41 \\
\hline & & & \pm 1.65 & \pm 1.83 & \pm 1.68 & \pm 1.42 & \pm 1.81 \\
\hline & Without spacing & Local & -1.12 & -0.80 & -0.27 & -0.62 & -0.67 \\
\hline & & & \pm 0.10 & \pm 0.66 & \pm 0.81 & \pm 0.71 & \pm 1.20 \\
\hline & & Global & -0.79 & -0.82 & -0.79 & -0.67 & -0.65 \\
\hline & & & \pm 1.50 & \pm 1.79 & \pm 1.75 & \pm 1.64 & \pm 1.31 \\
\hline \multirow[t]{8}{*}{ Low AQ } & With spacing & Local & -1.57 & -1.50 & -1.33 & -1.22 & -1.33 \\
\hline & & & \pm 1.15 & \pm 1.11 & \pm 1.39 & \pm 1.13 & \pm 1.02 \\
\hline & & Global & -1.31 & -1.19 & -0.61 & -0.88 & -0.77 \\
\hline & & & \pm 1.24 & \pm 1.32 & \pm 1.06 & \pm 1.03 & \pm 1.01 \\
\hline & Without spacing & Local & -1.67 & -1.76 & -1.45 & -1.61 & -1.28 \\
\hline & & & \pm 1.52 & \pm 1.62 & \pm 1.45 & \pm 1.29 & \pm 1.28 \\
\hline & & Global & -0.71 & -0.59 & -0.70 & -0.71 & -0.38 \\
\hline & & & \pm 1.06 & \pm 1.06 & \pm 1.07 & \pm 1.14 & \pm 0.71 \\
\hline
\end{tabular}

$($ Mean $\pm S D)$

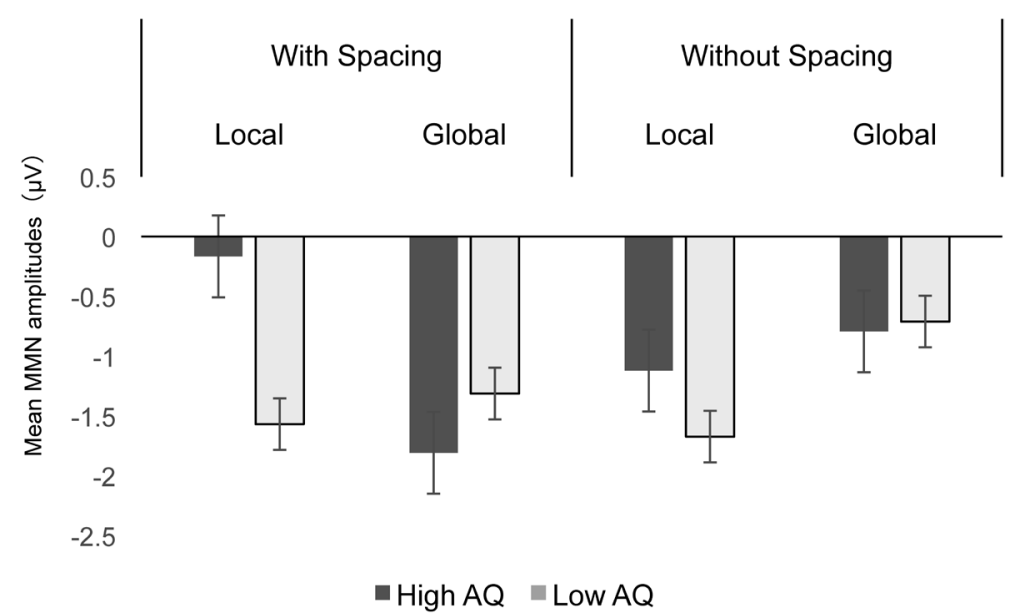

Figure 4. Mean MMN amplitudes at Fz. Each error bar shows \pm 1 standard error of mean.

処理傾向を持つというこの結果は, ASD傾向と同様 に, 感覚処理傾向の偏りに関しても, ASD児者と定 型発達児者との間に連続性が存在する可能性を示唆し ている。

\section{ASD傾向と局所・大域的逸脱に対する MMN}

各波形においてMMNが出現したといえるかどうか の判定を Näätänen et al. (2004)の方法を用いて検討 した結果, AQ高群の間隔有り条件における局所的逸
脱に対する差波形ではMMNが出現していないと判定 できる。次に電極部位Fzにおける各波形の MMN振 幅を従属変数とした，グループ ( $\mathrm{AQ}$ 高群, $\mathrm{AQ}$ 低群) $\times$ パターン間隔（間隔有り，間隔無し) $\times$ 逸脱の種類 (局所, 大域) の3 要因分散分析の結果, グループと逸 脱の種類との間に交互作用が認められ，局所的逸脱に 対する MMN振幅は, $\mathrm{AQ}$ 高群よりも $\mathrm{AQ}$ 低群の方が 有意に大きいことが示された。これら二つの結果か ら, AQ高群では, AQ低群よりも局所的逸脱に対す 
るMMNが出現しにくいといえる。

ASDは局所的変化に敏感であるという特性がある ため, 本研究において, AQ高群はAQ低群よりも局 所的逸脱に対するMMN振幅が大きいと予想した。し かし, 本研究では逆の結果が示された。以下では, そ の理由について考察する。まず，局所的逸脱に対し MMNが出現しなかったことはAAAABパターン全体 が標準刺激の聴覚記憶として保持されたと解釈でき る。なぜなら, 本研究の結果において, 大域的逸脱 (AAAAA)に対するMMNはAQ高群においても出現 しているためである。大域的逸脱に対する MMNが出 現するには，Sussman（2007）によれば，その標準刺 激としてAAAABというパターンが聴覚記憶として 保持される必要がある。つまり本研究において大域的 冕脱に対するMMNが出現し局所的冕脱に対する MMNが出現しなかったということは, 局所的逸脱を 含むパターン $(\mathrm{AAAAB})$ が聴覚記憶として保持され ていたことになる。このことから本研究の結果は, $\mathrm{AQ}$ 高群が $\mathrm{AQ}$ 低群よりもパターンの聴覚記憶を保持 しやすい特性があることを示していると考えられる。

それでは, なぜ $\mathrm{AQ}$ 高群でパターンの聴覚記憶保持 が優勢に行われたのだろうか。パターンの聴覚記憶が 保持されるためには，まず5音 1 セットのパターンが $\mathrm{A}$ 音4つと $\mathrm{B}$ 音1つで構成されていることが知覚され る必要がある。つまりパターンの聴覚記憶が形成され るためにはパターンの規則性を捉える必要があり, そ のためには局所的変化を知覚する必要があると考えら れる。このように考えると本研究の結果は, AQ高群 では，まず局所的変化に敏感であるという特性により $\mathrm{A}$ 音と $\mathrm{B}$ 音の差をいち早く探知し, 繰り返し呈示され ることでパターンの規則性が聴覚記憶に保持されたた め, AQ低群よりも局所的逸脱に対する $\mathrm{MMN}$ 振幅が 小さくなったと考えることができる。

Mottron et al. (2006) は, 知覚機能立進 (Enhanced perceptual functioning: EPF) モデルを提唱している。 このモデルでは, ASDは定型発達に比べ, 大域的知 覚よりも局所的知覚を指向する傾向があるとしてい る。このモデルに従えば, 本研究における $\mathrm{AQ}$ 高群に おいても, 刺激呈示開始初期の段階においては大域的 逸脱より局所的逸脱の知覚が優位に行われたと予想で きる。しかし，本研究に抒いては，局所的逸脱が規則 性を持って繰り返し呈示されたことで局所的逸脱が逸
脱として知覚されなくなり, 局所的逸脱の知覚よりも 大域的逸脱の知覚が優位に行われるようになったと考 えられる。これは, 非注意条件下に扔いて, 規則性の ある刺激を繰り返し呈示することは, ASD傾向が高 い成人の知覚傾向を局所的知覚から大域的知覚へとシ フトさせることを示唆していると考えられる。このこ とを日常場面に置き換えると, 例えば聞き取りによる 文章理解など大域的な知覚が必要とされる場面におい て，文章を繰り返し聴かせることにより ASDの文章 理解が促進されると考えられる。

\section{パターン間隔と局所・大域的逸脱に対する $\mathrm{MMN}$}

電極部位 $\mathrm{Fz} に お け る$ 各波形の MMN振幅を従属変 数とした, グループ ( $\mathrm{AQ}$ 高群, $\mathrm{AQ}$ 低群 $) \times$ パターン 間隔 (間隔有り, 間隔無し) $\times$ 逸脱の種類 (局所, 大域) の3 要因分散分析の結果, 条件と逸脱の種類との間に 交互作用がみられた。単純主効果の検定の結果, 間隔 有り条件の方が間隔無し条件よりも大域的逸脱に対す る差波形の MMN振幅が有意に大きいことと, 間隔有 り条件において，局所的逸脱に対する差波形よりも大 域的逸脱に対する差波形の MMN振幅の方が有意に大 きいことが示された。この結果から，パターン間の間 隔は大域的逸脱に対する MMN振幅を増大させる効果 があるといえる。パターン間に間隔が有ることによっ て5音1セットのパターンが強調されたため, 大域的 逸脱に対する MMN振幅が大きかったと考えられる。 一方, パターン間に間隔が有る場合, 局所的逸脱は 5 音1セットのパターンの一部として知覚されやすくな るため, 局所的逸脱に対する $\mathrm{MMN}$ 振幅は小さかった と考えられる。このことからパターン間の間隔は, ASD傾向の高低にかかわらず，大域的逸脱を探知し やすくする効果があると言える。このことを日常場面 に置き換えると，例えば文章を聴かせる際，文章を適 切な単位に区切って聴かせることが, ASDの文章理 解を促進すると考えられる。

\section{結 論}

本研究では, ASD傾向と感覚処理傾向との関連, ASD傾向の高低と局所的・大域的逸脱に対する $\mathrm{MMN}$ との関連, パターン間隔と局所・大域的逸脱に 対するMMNとの関連について検討した。その結果， ASD傾向と感覚処理傾向との間に関連が示され, 定 
型発達者とASD との間に感覚処理傾向の連続性が示 唆された。また, ASD傾向が高い成人では, ASD傾 向の低い成人に比ベパターンの聴覚記憶保持が優位に 行われることが示唆され, その結果, 局所的逸脱に対 するMMNが出現しにくくなると考えられた。さら に, パターン間隔は大域的逸脱の探知を促進すること で, 大域的逸脱に対する $\mathrm{MMN}$ を出現しやすくするこ とが示された。

\section{引用文献}

American Psychiatric Association (2013). Diagnostic and statistical manual of mental disorders (5th ed.). (DSM-5). Washington, DC: American Psychiatric Association.

Baron-Cohen, S., Campbell, R., Karmiloff-Smith, A., Grant, J., \& Walker, J. (1995). Are children with autism build to the mentalistic significance of the eyes? British Journal of Developmental Psychology, 13, 379-398.

Baron-Cohen, S., Wheelwright, S., Skinner, R., Martin, J., \& Clubley, E. (2001). The autism spectrum quotient (AQ): Evidence from Asperger syndrome/high-functioning autism males and females, scientists and mathematicians. Journal of Autism and Developmental Disorders, 31, 5-17.

Bekinschtein, T. A., Dehaene, S., Rohaut, B., Tadel, F., Cohen, L., \& Naccache, L. (2009). Neural signature of the conscious processing of auditory regularities. Proceedings of the National Academy of Sciences of the U.S.A., 106, 1672-1677.

Brown, C., \& Dunn, W. (2002). Adolescent-adult sensory profile: User's manual. San Antonio, TX: Therapy Skill Builders.

Crane, L., Goddard, L., \& Pring, L. (2009). Sensory processing in adults with autism spectrum disorders. Autism, 13, 215-228.

Dunn, W. (1997). The impact of sensory processing abilities on the daily lives of young children and their families: A conceptual model. Infants and Young Children, 9, 23-25

Dunn, W. (1999). The sensory profile: User's manual. San Antonio, TX: Psychological Corporation.
Frith, U., Mortron, J., \& Leslie, A. M. (1991). The cognitive basis of a biological disorder: Autism. Trends in Neurosciences, 14, 433-438.

Gomot, M., Giard, M. H., Adrien, J. L., Barthelemy, C., \& Bruneau, N. (2002). Hypersensitivity to acoustic change in children with autism: Electrophysiological evidence of left frontal cortex dysfunctioning. Psychophysiology, 39, 577-584.

萩原 拓・岩永 竜一郎・伊藤 大幸・谷伊織 (2015). $\mathrm{AASP}$ 青年・成人感覚プロファイルユーザーマ ニュアル 日本文化科学社

Heaton, P., Pring, L., \& Hermelin, B. (1999) . A pseudo-savant: A case of exceptional musical splinter skills. Neurocase, 5, 503-509.

Leekam, S. R., Nieto, C., Libby, S. J., Wing, L., \& Gould, J. (2007). Describing the sensory abnormalities of children and adults with autism. Journal of Autism and Developmental Disorders, 37, 894-910.

Mottron, L., Peretz, I., \& Menard, E. (2000). Local and global processing of music in high-functioning persons with autism: Beyond central coherence? Journal of Child Psychology and Psychiatry, and Allied Disciplines, 41, 1057-1065.

Mottron, L., Dawson, M., Soulieres, I., Hubert, B., \& Burack, J. (2006). Enhanced perceptual functioning in autism: An update, and eight principles of autistic perception. Journal of Autism and Developmental Disorders, 36, 27-43.

Näätänen, R., Gaillard, A. W., \& Mäntysalo, S. (1978). Early selective-attention effect on evoked potential reinterpreted. Acta Psychologica, 42, 313-329.

Näätänen, R., Pakarinen, S., Rinne, T., \& Takegata, R. (2004). The mismatch negativity (MMN): Towards the optimal paradigm. Clinical Neurophysiology, 115, 140-144.

Sussman, E. S. (2007). A new view on the MMN and attention debate: The role of context in processing auditory events. Journal of Psychophysiology, 21, 164-175.

Sussman, E., \& Gumenyuk, V. (2005). Organization 
of sequential sounds in auditory memory. Neuroreport, 16, 1519-1523.

Sussman, E., Ritter, W., \& Vaughan, H.G. Jr. (1998). Attention affects the organization of auditory input associated with the mismatch negativity system. Brain Research, 789, 130-138.

Sussman, E., Winkler, I., Huotilainen, M., Ritter, W., \& Näätänen, R. (2002). Top-down effects can modify the initially stimulus-driven auditory organization. Cognitive Brain Research, 13, 393-405.

若林 明雄 - 東條吉邦 - Baron-Cohen, S. Wheelwright, S. (2004). 自閉症スペクトラム指数（AQ）日本 語版の標準化 心理学研究, 75, 78-84.

Wing, L. (1981). Asperger's syndrome: A clinical account. Psychological Medicine, 11, 115-129. 